\title{
Cytotoxic Polyketides from the Marine Sponge Discodermia calyx
}

\author{
Pramod B. Shinde, Tayyab A. Mansoor, Xuan Luo, Jongki Hong, ${ }^{\dagger}$ Chong-O. Lee, ${ }^{\ddagger}$ and Jee H. Jung ${ }^{\star}$ \\ College of Phamacy, Pusan National Chiversit, Busan 609-735, Korea. ${ }^{\star}$ E-mall: jhjungâpusan ac.hr \\ ${ }^{\dagger}$ College of Phamacy, Kunng Hee Lmiversin. Seoul 136-701. Korea \\ -Pharnaceutical Screening Center, Korea Research Instinte of Chemical Technologv, Daejon 305-343, Korea \\ Received December 22, 2006
}

\begin{abstract}
Bioassay-guided fractionation of the $\mathrm{MeOH}$ extract from the sponge Discodermia calvx collected off the coast of Jeju Island. South Korea, led to the isolation of a polyketide, icadamide C (1). along with previously reported theopederin $\mathrm{K}$ (3). Structure elucidation was performed by a combination of high resolution mass and 2D-NMR (principally COSY. HMBC, HSQC. and NOESY) spectroscopy. Stereochenistry of conpound 1 was determined as $2 R^{*} .3 R^{*} .6 R^{*}, 10 S^{*} .11 S^{*}, 12 R^{*} .135^{*} .15 R^{*}$ and $2^{\prime} S^{\prime}$ by NMR data and Marfey analysis. Isolated metabolites displayed potent cy totoxic activity against a small panel of five human solid tumor cell lines with $\mathrm{ED}_{3 \mathrm{ij}}$ values of less than $0.1 \mu \mathrm{g} / \mathrm{mL}$.
\end{abstract}

Key Words : Marine sponge. Discodermia calvx. Polyketide. Cytotoxicity. Marfey analy'sis

\section{Introduction}

Sponges of the order Lithistida (subclass Tetractinomorpha) are well known for producing a wide range of secondary metabolites, including macrolides and peptides. Marine sponges belonging to the genus Discodermia are a promising source of diverse chemical metabolites. The marine sponge Discodermia callx (order Lithistida, family Theonellidae) is reported to contain the calyculins. ${ }^{1-6}$ unique polyketides bearing nitrogen and phosphorus functions. These macrolides exhibit a variety of biological activities including antitumor and smooth muscle contractile, which are attributed to inhibition of protein phosphatase $\mathrm{I}$ and $2 \mathrm{~A} .{ }^{5}$ Three sulfated ceramides, calyceramides. have also been isolated from the same sponge as inhibitors of neuraminidase. $^{?}$

As a part of our continuing research aimed at the discovery of biologically active secondary metabolites from marine organisms, ${ }^{8-110}$ we isolated two C.21 furanoterpenes and eight bisindole alkaloids from the marine sponge Discodermiacallox, as a first report from a sponge belonging to the subclass Tetractinomorpha. ${ }^{11}$ In the continuation of our study on this marine sponge, we isolated two pederin polyketides (1 and 3) from the $90 \% \mathrm{MeOH}$ fraction. This paper deals with the isolation. structure elucidation, and cytotoxicity evaluation of polyketides ( $\mathbf{1}$ and $\mathbf{3}$ ).

\section{Results and Discussion}

The $\mathrm{MeOH}$ crude extract of Discodermia cally was subjected to activity-guided fractionation using solvent partition and reversed-phase flash column chromatography followed by repeated reversed-phase HPLC to yield contpounds 1 and 3. The structures of these metabolites were deduced using NMR $\left({ }^{1} \mathrm{H},{ }^{13} \mathrm{C}, \mathrm{COSY}\right.$. HSQC. HMBC. and NOESY $)$ and MS analysis. and optical rotation data.

Compound 1 was obtained as colorless oil, and its mole- cular formula was established as $\mathrm{C}_{38} \mathrm{H}_{61} \mathrm{~N}_{5} \mathrm{O}_{12}$ on the basis of HRFABMS and NMR data (Table 1). The exact mass of the $[\mathrm{M}+\mathrm{Na}]^{+}$ion (mz 802.4234) matched well with the expected molecular formula $\mathrm{C}_{32} \mathrm{H}_{61} \mathrm{~N}_{5} \mathrm{O}_{12}(\Delta+2.0 \mathrm{mmu})$. The ${ }^{1} \mathrm{H}$ NMR spectrum revealed signals of an exo-methylene $\left(\delta_{\mathrm{H}}\right.$ 4.64 and 4.80$)$, a disubstituted double bond $\left(\delta_{\mathrm{H}} 5.18\right.$ and $5.75)$, a conjugated diene $\left(\delta_{\mathrm{H}} 6.18 .6 .32 .7 .15\right.$. and 6.06$)$, tluree methoxy groups $\left(\delta_{\mathrm{H}} 3.19 .3 .51\right.$. and 3.19). seven oxymethine protons $\left(\delta_{\mathrm{H}} 3.90 .4 .26,3.89 .4 .13,3.48 .3 .26\right.$, and 3.59). and four methyl groups $\left(\delta_{\mathrm{H}} 0.83 .0 .96 .0 .98\right.$. and 1.18). ${ }^{13} \mathrm{C}$ NMR data (assigned by HMBC and HSQC experiments) of 1 exhibited three carbonyl carbon signals at $\delta_{C} 168.0(\mathrm{C}-25), 174.0(\mathrm{C}-8)$, and $178.0\left(\mathrm{C}-\mathrm{l}^{\prime}\right)$, and one ketal carbon signal at $\delta_{C} 101.0(\mathrm{C}-6)$. A signal at $\delta_{C} 158.0$ was assigned as a guanidine carbon of arginine. and this analy sis confirmed close relationship with the bioactive metabolites known as theopederins, ${ }^{13-14}$ mycalamides, ${ }^{15.18}$ and onnamides. ${ }^{19-22}$ Analysis of the ${ }^{1} \mathrm{H} \cdot{ }^{1} \mathrm{H}$ COSY spectrum revealed the presence of four spin sy stems comprising $\mathrm{H}_{3}-26$ to $\mathrm{H}_{3}-27$. $\mathrm{H}$ 10 to $\mathrm{H}-13, \mathrm{H}-15$ to $\mathrm{H}-24$, and $\mathrm{H}-2^{\prime}$ to $\mathrm{H}-5^{\prime}$. Moreover, analysis of the HMBC spectrum confimmed connectivities of these partial structures into one molecule (Fig. 2). After careful comparison with reported NMR data. it was clear that the obtained data of 1 was quite similar with that of icadamide A (2). which was previously isolated from a marine sponge Leiosella sp. (order Dictyoceratida, family Spongiidae, ${ }^{-3}$ except one additional methoxyl group attached to $\mathrm{C}-17$. Therefore. compound 1 was defined as 17-Omethyl derivative of icadamide A (2). There have been reports on the isolation of $O$-methylated derivatives along with parent compounds i.e. theopederins $\mathrm{K}(3)$ and $\mathrm{L}(\boldsymbol{t}){ }^{1+}$ mycalamides A (5) and B (6). ${ }^{16}$ It was mentioned that to eliminate the possibility that methoxyl group was solvent derived, an extraction of the Mycale sponge was again carried out with ethanol instead of methanol. which led to the isolation of the same mycalamides A (5) and B (6). ${ }^{16}$ From above discussion, it can be assumed that icadamide $\mathrm{C}$ 
Table 1. 1D and 2D NMR Data for 1 in $\mathrm{CD}_{3} \mathrm{OD}$ at $500 \mathrm{MHz}$

\begin{tabular}{|c|c|c|c|c|}
\hline position & $\dot{\alpha}^{a}$ & $\hat{\mathrm{H}}_{\mathrm{H}}(\mathrm{mult}, J=\mathrm{Hz})$ & $\cos Y$ & $\mathrm{HMBC}$ \\
\hline 2 & 70.5 & $3.90^{b}$ & $\mathrm{H}-26, \mathrm{H}-3$ & \\
\hline 3 & 42.5 & $2.20(\mathrm{~m})$ & $\mathrm{H}-27, \mathrm{H}-2$ & $\mathrm{C}-4, \mathrm{C}-28$ \\
\hline 4 & 147.5 & & & \\
\hline $5 a$ & 34.2 & $2.41(\mathrm{~d}, 14.0)$ & $\mathrm{H}-5 b$ & $\mathrm{C}-4, \mathrm{C}-28, \mathrm{C}-6$ \\
\hline $5 b$ & & $2.31(\mathrm{~d}, 14.0)$ & $\mathrm{H}-5 \mathrm{a}$ & $\mathrm{C}-4, \mathrm{C}-28, \mathrm{C}-6, \mathrm{C}-3$ \\
\hline 6 & 101.0 & & & \\
\hline 7 & 73.0 & $4.26(s)$ & & $C-5, C-8, C-6$ \\
\hline 8 & 174.0 & & & \\
\hline 10 & 75.2 & $5.63(\mathrm{~d}, 9.0)$ & $\mathrm{H}-1 \mathrm{l}$ & $\mathrm{C}-8$ \\
\hline 11 & 70.2 & $3.89^{\circ}$ & $\mathrm{H}-10, \mathrm{H}-12$ & \\
\hline 12 & 74.5 & $4.13(\mathrm{dd}, 9.5,6.0)$ & $\mathrm{H}-11, \mathrm{H}-13$ & $\mathrm{C}-13, \mathrm{C}-29, \mathrm{C}-10$ \\
\hline 13 & 80.6 & $3.48^{b}$ & $\mathrm{H}-12$ & \\
\hline 14 & 41.0 & & & \\
\hline 15 & 76.8 & $3.26^{b}$ & $\mathrm{H}-16$ & \\
\hline 16 & 35.8 & $1.47(\mathrm{dd}, 10.5,3.5)$ & $\mathrm{H}-17, \mathrm{H}-15$ & \\
\hline 17 & 81.5 & $3.59(111)$ & $\mathrm{H}-18, \mathrm{H}-16$ & \\
\hline 18 & 132.5 & $5.18(\mathrm{dd}, 150,8.0)$ & $\mathrm{H}-19, \mathrm{H}-17$ & $C-20$ \\
\hline 19 & 134.0 & $5.75(\mathrm{dt}, 15.0,7.0)$ & $\mathrm{H}-18, \mathrm{H}-20$ & $C-17, C-20$ \\
\hline 20 & 36.2 & $2.97(\mathrm{~m})$ & $\mathrm{H}-21, \mathrm{H}-19$ & $\mathrm{C}-21, \mathrm{C}-19, \mathrm{C}-18, \mathrm{C}-22$ \\
\hline 21 & 141.8 & $6.18(\mathrm{dt}, 14.0,7.0)$ & $\mathrm{H}-22, \mathrm{H}-2 \mathrm{O}$ & $C-20$ \\
\hline 22 & 130.5 & $6.32(\mathrm{dd}, 14.0,10.0)$ & $\mathrm{H}-23, \mathrm{H}-2 \mathrm{l}$ & C-23 \\
\hline 23 & 140.6 & $7.15(\mathrm{dd}, 150,10.0)$ & $\mathrm{H}-22, \mathrm{H}-24$ & $C-25$ \\
\hline 24 & 123.4 & $6.06(\mathrm{~d}, 15.0)$ & $\mathrm{H}-23$ & $\mathrm{C}-22, \mathrm{C}-25$ \\
\hline 25 & 168.0 & & & \\
\hline 26 & 18.4 & $1.18(\mathrm{~d}, 6.5)$ & $\mathrm{H}-2$ & $C-2, C-3$ \\
\hline 27 & 12.6 & $0.98(\mathrm{~d}, 7.0)$ & $\mathrm{H}-3$ & $\mathrm{C}-4, \mathrm{C}-2, \mathrm{C}-3$ \\
\hline $28 \mathrm{a}$ & 110.0 & $4.80^{6}$ & & $C-3, C-5$ \\
\hline $28 b$ & & $4.6+(b r s)$ & & $C-3, C-5$ \\
\hline $29 \mathrm{a}$ & 87.0 & $5.12(\mathrm{~d}, 7.0)$ & $\mathrm{H}-29 \mathrm{~b}$ & $C-12$ \\
\hline $29 \mathrm{~b}$ & & $4.78^{b}$ & $\mathrm{H}-29 \mathrm{a}$ & \\
\hline 30 & 23.5 & $0.96(s)$ & & $\mathrm{C}-13, \mathrm{C}-14, \mathrm{C}-15$ \\
\hline 31 & 13.5 & $0.83(\mathrm{~s})$ & & $C-13, C-14, C-15, C-30$ \\
\hline $6-\mathrm{OCH}_{3}$ & 42.0 & $3.19(\mathrm{~s})$ & & \\
\hline $13-\mathrm{OCH}_{3}$ & 61.0 & $3.51(s)$ & & $C-13$ \\
\hline 17- $\mathrm{OCH}_{3}$ & 55.8 & $3.19(\mathrm{~s})$ & & $C-17$ \\
\hline $\mathrm{l}^{\prime}$ & 178.0 & & & \\
\hline $2^{\prime}$ & 55.0 & $4.34(\mathrm{dd}, 7.0,5.5)$ & $\mathrm{H}-3^{\prime} a, \mathrm{H}-3^{\prime} b$ & $C^{\prime}-1^{\prime}$ \\
\hline $3 \mathrm{a}$ & 31.2 & $1.88(\mathrm{~m})$ & $\mathrm{H}-2^{\prime}, \mathrm{H}-3^{\prime} b, \mathrm{H}-4^{\prime}$ & $C^{\prime}-2 ; C-1^{\prime}, C-5^{\prime}, C-1^{\prime}$ \\
\hline 3 'b & & $1.72(\mathrm{~min})$ & $\mathrm{H}-3^{\prime} a, \mathrm{H}-2^{\prime}, \mathrm{H}-4^{\prime}$ & \\
\hline $4^{\prime}$ & 25.8 & $1.60(\mathrm{~m})$ & $\mathrm{H}-5^{\prime}, \mathrm{H}-3 \mathrm{a}, \mathrm{H}-3^{\prime} b$ & $C-2, C-5^{\prime}, C-3$ \\
\hline $5^{\prime}$ & 42.0 & $3.19^{6}$ & $\mathrm{H}-\mathrm{I}^{\prime}$ & $C-7^{\prime}$ \\
\hline $7^{1}$ & 158.0 & & & \\
\hline
\end{tabular}

"Signals were assigned by HMBC and HSQC experiments. ${ }^{k}$ Overlapped with other signals.

(1) is also a natural product rather than an artifact produced during isolation.

${ }^{1} \mathrm{H}-{ }^{1} \mathrm{H}$ coupling constants and the ${ }^{13} \mathrm{C}$ NMR data, which were almost superimposable on those of icadamide A (2). suggested the identical relative stereochemistry for 1 . The relative stereochemistry of 1 was further confirmed on the basis of NOESY data (Fig. 3) and analysis of coupling constants. The cis fusion of the tetrahydropyran ring and the dioxane ring was assigned from the small coupling constant $\left(J_{11,13}=6.0 \mathrm{~Hz}\right.$ ) between $\mathrm{H}_{\mathrm{el}}-1 \mathrm{l}$ and $\mathrm{H}_{\mathrm{ax}}-12$ (troms fusion: $J$ $=\sim 10.0 \mathrm{~Hz})^{24.36}$ This was further confirmed from the NOESY correlation between $\mathrm{H}_{4 x}-10$ and $\mathrm{H}_{\mathrm{ax}}-15$ (trams fusion would demand different correlations). NOESY correlations between $\mathrm{H}_{4 x}=10 / \mathrm{H}_{4 x}-15$. $\mathrm{H}_{4 \mathrm{x}}=10 / \mathrm{H}_{4 \mathrm{x}}-29$. and $\mathrm{H}_{\mathrm{ax}}=13 / \mathrm{H}_{\mathrm{ax}}=29$ indicated their spatial proximity. Furthermore, NOESY correlations $\mathrm{H}_{3}-27$ to $\mathrm{H}_{4 \times}-5 . \mathrm{H}_{\mathrm{ax}}=2$ to $\mathrm{H}_{3}-6-\mathrm{OCH}_{3}$. and $\mathrm{H}_{\mathrm{ax}}=12$ to $\mathrm{H}_{2}-31$ showed $1,3-$ diaxially oriented configurations. The trons geometry for double bonds was assigned from the large coupling constants $(J=14 \sim 15 \mathrm{~Hz})$. Thus, the relative stereochemistry of the ring carbons of compound 1 was 


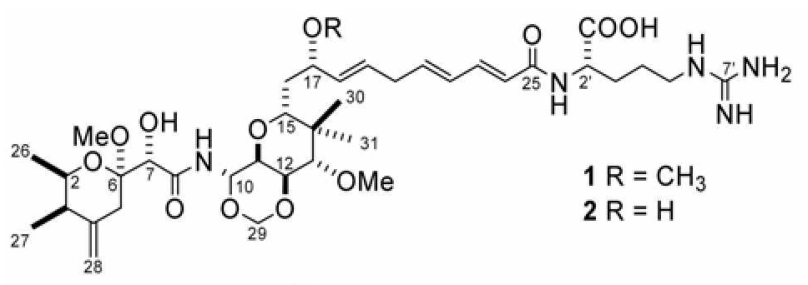

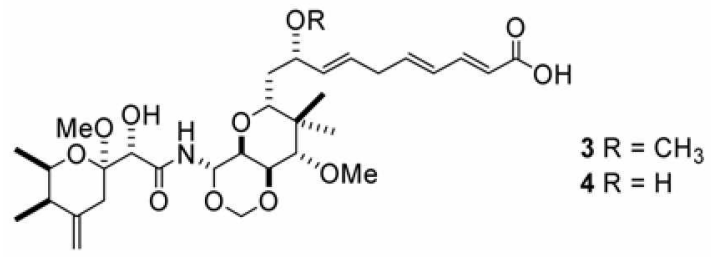

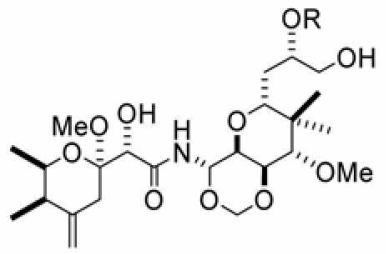

$5 \mathrm{R}=\mathrm{H}$

$6 \mathrm{R}=\mathrm{CH}_{3}$<smiles>C=C1C[C@](OC)([C@H](O)C(=O)NC2OCOC3C2O[C@H](C[C@H](O)CCCC=CC=CC=CC(=O)N[C@@H](CCCNC(=N)N)C(=O)O)C(C)(C)[C@H]3OC)OC(C)C1C</smiles>

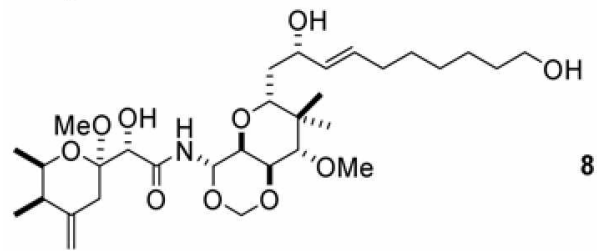

Figure 1. Structures of compounds 1-8.

determined to be $2 R^{*}, 3 R^{*}, 6 R^{*}, 10 S^{*}, 11 S^{*}, 12 R^{*}, 13 S^{*}$, and $15 R^{*}$. The absolute configuration of the arginine portion of 1 was defined as $S$, the same as $\mathbf{2}$ and $\mathbf{7}$. Acid hydrolysis of $\mathbf{1}$ and derivatization with Marfey's reagent ${ }^{7}$ followed by HPLC analysis. established L-configuration for arginine. Small amount of icadamide C (1) did not permit us to define absolute stereochemistry at $\mathrm{C}-7$ and $\mathrm{C}-17$. However. the optical rotation showed the same sign as other pederin class of compounds $\left(1:[\alpha]_{\mathrm{D}}^{31}+35.8^{\circ}\right.$, MeOH: $2:[\alpha]_{\mathrm{D}}+81^{\circ}$. $\mathrm{MeOH}: 7:[\alpha]_{\mathrm{D}}+99.1^{\circ}$. MeOH). Therefore. the absolute configuration of 1 was presumed to be the same with reported analogous compounds.

Compound 3 was isolated as white solid. The HRFABMS of 3 supported the molecular fomula $\mathrm{C}_{33} \mathrm{H}_{49} \mathrm{NO}_{11}$. The exact mass of the $[\mathrm{M}+\mathrm{Na}]^{-}$ion $(\mathrm{mz} 646.3197)$ matched well with the expected molecular formula $\mathrm{C}_{33} \mathrm{H}_{49} \mathrm{NO}_{11}(\Delta-0.5 \mathrm{mmu})$. The ${ }^{1} \mathrm{H}$ NMR spectrum of 3 showed marked similarities to that of 1 , which indicated that 3 also belong to the pederin class. Compound 3 was identified as theopedrin $\mathrm{K}$ by comparison of NMR. MS spectral. and optical rotation data with those of reported. which was previously isolated from a marine sponge Discodermia sp. ${ }^{1+}$

Icadamide A (2) and B (8) were reported to show in vitro

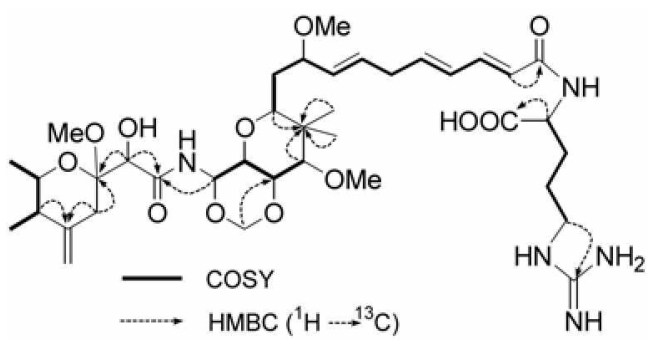

Figure 2. Key COSY and HMBC correlations for compound 1

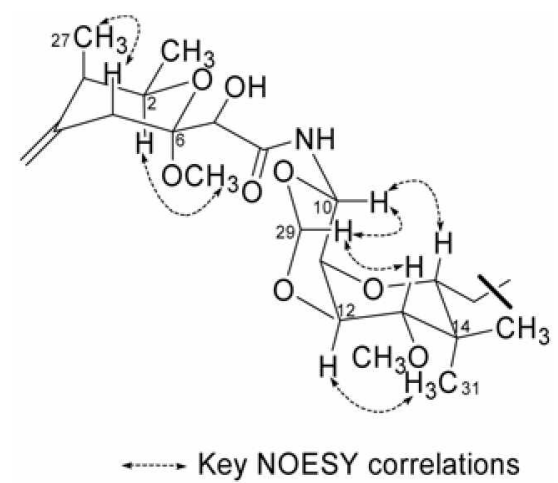

Figure 3. Relative stereochemistry of compound 1.

cytotoxicity against HCT-116 human colon carcinoma cell line with $\mathrm{IC}_{\text {sul value of }} 63 \mathrm{nM}$ and $0.17 \mathrm{nM}$, respectively. Among pederin type of compounds, only icadamide B (8) was studied for in vino antitumor activity and exhibited activity against intraperitoneally and subcutaneously implanted tumors such as P-388 mouse leukemia, Ml09 mouse lung tumors, and asbestos-induced pulmonary squamous cell carcinoma ${ }^{23}$ Compound 3 was reported to demonstrate in vitro cy totoxicity against the cultured murine P-388 tumor cell line and the human lung adenocarcinoma A-549 cell line, with $\mathrm{IC}_{s, 1}$ values of $0.1 \mathrm{nM}$ and $1.5 \mathrm{nM}$. respectively. ${ }^{1+}$ The cytotoxicity of the isolated compounds against A-549, SK-OV-3. SK-MEL-2. XF-498. and HCT-15 solid tumor cell lines was studied. The results (Table 2) showed that both compounds ( $\mathbf{1}$ and $\mathbf{3}$ ) are potent cytotoxins against all of the cell lines tested. Moreover. it can be concluded that the presence of arginine group has negative effect on the cytotoxic profile of compound 1 .

There have been a number of reports on the isolation of pederins from numerous terrestrial insects and marine sponges. The first compound. pederin. was isolated in 1953 from the beetle Paederus fouscipes. ${ }^{28}$ and thereafter scientists started reporting similar compounds from marine sponges. which are completely different source from terrestrial beetles. The taxonomy of these marine sponges is quite different as shown here: Micale sp..$^{15.16 .18}$ and Siyinos sp. ${ }^{17}$ (subclass Ceractinomorpha, order Poescilosclerida, family Mycalidae). Leiosella sp. (subclass Ceractinomorpha. order Dictyoceratida. family Spongiidae) ${ }^{23}$ Theonella sp..$^{1 ., 13.16 .18}$ and Discodermia sp. ${ }^{14}$ (subclass Tetractinomorpha, order Lithistida. family Theonellidae). and Trachyclachts laemsprralifer (subclass Tetractinomorpha, order Axinellida, fanily 
Table 2. Cy totoxicity Data of Compounds 1 and $3^{a}$

\begin{tabular}{lllccc}
\hline compound & A-5 49 & SK-OV-3 & SK-MEL-2 & XF-498 & HCT-15 \\
\hline $\mathbf{1}$ & 0.019 & 0.025 & 0.01 & 0.017 & 0.014 \\
$\mathbf{3}$ & 0.0003 & 0.0005 & 0.0001 & 0.0001 & 0.0001 \\
doxonubicin & 0.029 & 0.11 & 0.016 & 0.015 & 0.10 \\
\hline
\end{tabular}

"Data expressed in ED $5 n$ values ( $u$ g mL). A-549, human lung cancer; SK-OV-3. human ovarian cancer: SK-MEL-2. human skin cancer: XF-498. human CNS cancer: HCT-15, human colon cancer.

Spirastrellidae). $\hat{\imath}$ Reports on isolation of pederin class of compounds from taxonomically distant organisms indicate the possible nicrobial origin of the compounds.

\section{Experimental Section}

General procedures. Optical rotations were measured with a Jasco P- 1020 polarimeter using a I dm path length cell. The ${ }^{1} \mathrm{H}$ and $2 \mathrm{D}$ NMR spectra were recorded at 500 $\mathrm{MHz}$ using Varian INOVA 500 spectrometer. FABMS data were obtained on a JEOL JMS SX-102A spectrometer. HRFABMS data were obtained on a JEOL JMS SX-101A spectrometer. Chemical shifts were reported with reference to the respective solvent peaks and residual solvent peaks ( $\delta_{\mathrm{H}} 3.30$ and $\delta_{\mathrm{C}} 49.0$ for $\mathrm{CD}_{3} \mathrm{OD}$ ). HPLC was performed on a Gilson 370 pump with a Shodex C.18M 10E (preparative. $250 \times 10 \mathrm{mun}$ i.d., $5 \mu \mathrm{ml} .100 \mathrm{~A}$ ) and YMC-Pack CN (preparative. $250 \times 10 \mathrm{~mm}$ i.d. $5 \mu \mathrm{m}, 120 \AA$ ) colununs using a Shodex RI-101 detector.

Animal material. The sponge was collected in November 2004 , off the coast of Jeju Island. South Korea, using scuba. The samples were frozen inmediately after collection and stored at $-20^{\circ} \mathrm{C}$ until extraction. This organism was identified as Discodermia calvx by Prof. Chung Ja Sin of Hanuan University. A voucher specimen (registry no. Spo. 49) was deposited in the Natural History Museum. Hannam University, Korea.

Extraction and Isolation. The freeze dried sponge Discodermia calvx $(4.5 \mathrm{~kg})$ was cut into small pieces and extensively extracted with $\mathrm{MeOH}$ at room temperature. The $\mathrm{MeOH}$ extract was partitioned between $\mathrm{CH}_{2} \mathrm{Cl}_{2}$ and $\mathrm{H}_{2} \mathrm{O}$. The $\mathrm{CH}_{2} \mathrm{Cl}_{2}$ layer $(8.0 \mathrm{gm})$ was further partitioned between aqueous $\mathrm{MeOH}$ and $n$-hexane. The aqueous $\mathrm{MeOH}$ fraction (4.2 gm) was subjected to a reversed-phase flash columun chromatography (YMC Gel ODS-A. 60 A 500/400 mesh). using gradient elution from 50 to $100 \% \mathrm{MeOH} / \mathrm{H}_{2} \mathrm{O}$ to yield nineteen fractions (DCI-DC 19). These fractions were evaluated for activity by the brine shrimp lethality assay ${ }^{29}$ and fractions DC4 and DC5 were selected for further separation on the basis of toxicity to brine shrimp larvae $\left(\mathrm{LD}_{5 i} 700 \mu \mathrm{g} /\right.$ $\mathrm{mL}$ and $132 \mu \mathrm{g} / \mathrm{mL}$, respectively). Fraction DC5 was further subjected to a reversed-phase HPLC on a Shodex CI8M $10 \mathrm{E}$ (preparative. $250 \times 10 \mathrm{~mm}$ i.d. $5 \mu \mathrm{m}, 100 \AA$ ) colunn. eluting with $65 \%$ aqueous $\mathrm{MeOH}(\mathrm{lmL} / \mathrm{min})$. to afford four subfractions. Compound $1(1.0 \mathrm{mg})$ was obtained by purifying subfraction DC5-3 by reversed-phase HPLC (Shodex C $18 \mathrm{M} 10 \mathrm{E}$. preparative. $250 \times 10 \mathrm{~mm}$ i.d. $5 \mu \mathrm{m}$. $100 \mathrm{~A}$ ). eluting with $40 \%$ aqueous $\mathrm{CH}_{3} \mathrm{CN}\left(2 \mathrm{~mL} / \mathrm{min}\right.$. $t_{\mathrm{R}} 15 \mathrm{~min}$.).
Similarly, fraction DC 4 was subjected to a reversed-phase HPLC on a Shodex CI8M 10E (preparative, $250 \times 10 \mathrm{~mm}$ i.d. $5 \mu \mathrm{m}$. $100 \AA$ ) column, eluting with $57 \%$ aqueous $\mathrm{MeOH}(2 \mathrm{~mL} / \mathrm{min})$, to afford six subfractions. Subfraction DC4-3 was subjected to reversed-phase HPLC (Shodex CI8M 10E. preparative, $250 \times 10 \mathrm{~mm}$ i.d., $5 \mu \mathrm{m}, 100 \AA$ ). eluting with $45 \%$ aqueous $\mathrm{CH}_{3} \mathrm{CN}(0.5 \mathrm{~mL} / \mathrm{min})$. to yield five subfractions. Compound 3 (1.2 $\mathrm{mg}$ ) was obtained by purification of subfraction DC4-3-1 by reversed-phase HPLC (YMC-Pack CN, preparative, $250 \times 10 \mathrm{~mm}$ i.d., $5 \mu \mathrm{m}$. 120 A), eluting with $20 \%$ aqueous $\mathrm{CH}_{3} \mathrm{CN}$ ( $1 \mathrm{~mL} / \mathrm{min}$. $t_{\mathrm{K}} 40$ nin.).

Marfey analysis of arginine: Compound $1(0.2 \mathrm{mg})$ was dissolved in $6 \mathrm{~N} \mathrm{HCl}(1 \mathrm{~mL})$ and hydrolyzed at $110^{\circ} \mathrm{C}$ for 12 h. The acid hydrolyzate was dried under $\mathrm{N}_{2}$, and to it was added $0.1 \%$ FDAA (Marfey's reagent, 1-fluro-2.4-dinitrophenyl-5-L-alanine amide) solution in acetone ( $100 \mu \mathrm{L})$ and $1 \mathrm{M} \mathrm{NaHCO}_{3}(20 \mu \mathrm{L})$ followed by heating at $60^{\circ} \mathrm{C}$ for $\mathrm{l} \mathrm{h}$. After cooling to room temperature. the reaction mixture was neutralized with $2 \mathrm{M} \mathrm{HCl}(10 \mu \mathrm{L})$ and diluted with $100 \mu \mathrm{L}$ of $\mathrm{MeOH}$. This solution was analyzed by reversed-phase preparative HPLC (Shodex CI8M 10 E. $250 \times 10 \mathrm{~mm}$ i.d.. 5 $\mu \mathrm{m}, 100 \AA$ ) column with isocratic elution ( $5 \%$ aqueous $\mathrm{MeOH}: 1 \mathrm{~mL} / \mathrm{min}$ ) to furnish a peak of L-Arg-FDAA complex $\left(t_{\mathrm{K}} 15 \mathrm{~min}\right.$.: D-Arg-FDAA complex: $t_{\mathrm{R}} 20 \mathrm{~min}$.).

Icadamide $C$ (1). colorless oil: $[\alpha]_{\mathrm{D}}^{\hat{1}}+35.8^{\circ}$ ( $c$ c 0.1 , $\mathrm{MeOH}):{ }^{1} \mathrm{H}$ and ${ }^{12} \mathrm{C}$ NMR data $\left(\mathrm{CD}_{3} \mathrm{OD}\right)$ see Table 1; LRFABMS $m=802.5[\mathrm{M}+\mathrm{Na}]^{+}$: HRFABMS $m z 802.4234$ $\left[\mathrm{M}+\mathrm{Na}^{-}\right.$(calc. for $\mathrm{C}_{38} \mathrm{H}_{61} \mathrm{~N}_{5} \mathrm{O}_{13} \mathrm{Na}, 802.42 \mathrm{l} 40$ ).

Theopederin $\mathbf{K}(3)$. white solid: $[\alpha]_{\mathrm{D}}^{2]}+59.9^{\circ}$ (c) 0.1 , $\mathrm{MeOH}):{ }^{1} \mathrm{H}$ NMR (CD $\left.\mathrm{OD}, 500 \mathrm{MHz}\right) \delta 7.05$ (lH. dd, $J=$ $15.0 .15 .0 \mathrm{~Hz} . \mathrm{H}-23), 6.26(1 \mathrm{H} . \mathrm{dd} . J=15.0 .15 .0 \mathrm{~Hz} . \mathrm{H}-22)$. $6.07(1 \mathrm{H}$, dt. $J=15.0 .7 .0 \mathrm{~Hz} . \mathrm{H}-21) .5 .85(1 \mathrm{H}, \mathrm{d} . J=15.0$ Hz. H-24). 5.75 (1H. dt $J=16.0 .6 .5 \mathrm{~Hz}, \mathrm{H}-19) .5 .64(1 \mathrm{H} . \mathrm{d}$. $J=9.0 \mathrm{~Hz}, \mathrm{H}-10) .5 .17(1 \mathrm{H}$. dd $J=16.0,9.5 \mathrm{~Hz}, \mathrm{H}-18)$. $5.12(1 \mathrm{H}$, d. $J=7.0 \mathrm{~Hz}, \mathrm{H}-29) .4 .80(1 \mathrm{H}$. overlapped. H28a), 4.78 (1H, overlapped. H-29). 4.64 (1H. br s. H-28b). 4.25 (1H, s. H-7), 4.13 (1H, dd. $J=9.0,5.5 \mathrm{~Hz}, \mathrm{H}-12), 3.91$ (1H. m. H-11), 3.89 (1H, overlapped. H-2), 3.58 (1H, m. H17). $3.52\left(3 \mathrm{H}, \mathrm{s} .13-\mathrm{OCH}_{3}\right), 3.41$ (1H. overlapped, $\left.\mathrm{H}-13\right)$, $3.28(\mathrm{lH}$, overlapped. $\mathrm{H}-15), 3.24\left(3 \mathrm{H}, \mathrm{s} .6-\mathrm{OCH}_{3}\right) .3 .16$ (3H. s, 17-OCH $), 2.94(2 \mathrm{H} . \mathrm{m}, \mathrm{H}-20), 2.41(\mathrm{lH} . \mathrm{d} . J=14.0$ Hz. H-5a). 2.31 (lH, d, $J=14.0 \mathrm{~Hz} . \mathrm{H}-5$ b) 2.19 (lH. m, H3). $1.48(2 \mathrm{H}$. dd. $J=11.5 .5 .5 \mathrm{~Hz} . \mathrm{H}-16) .1 .18(3 \mathrm{H} . \mathrm{d}, J=7.0$ Hz. H-26), $0.97(3 \mathrm{H}$, d. $J=7.0 \mathrm{~Hz}, \mathrm{H}-27), 0.95(3 \mathrm{H}, \mathrm{s} . \mathrm{H}-$ 30). 0.83 (3H, s. H-3l): LRFABMS $m z 646.4\left[\mathrm{M}+\mathrm{Na}^{-}\right.$: HRFABMS $m z 646.3197[\mathrm{M}+\mathrm{Na}]^{-}$(calc. for $\mathrm{C}_{32} \mathrm{H}_{49} \mathrm{NO}_{11} \mathrm{Na}$. $646.32020)$. 
Acknowledgments. Our thanks are due to Prof. Chung Ja Sim of Haluam University for the identification of the sponge. This study was financially supported by a grant from Marine Bio 21. Ministry of Maritime Affairs and Fisheries. Korea. P. B. S. is grateful to Korea Science and Engineering Foundation (KOSEF) for doctoral fellowship.

\section{References}

1. Kato, Y: Fusetani, N.: Matsumaga, S.: Hashimoto. K. J. Am. Chem. Soc. 1986. 108.2780

2. Kato. Y.: Fusetani. N.: Matsunaga. S.: Hashimoto. K. J. Org. Chem. 1988. 53.3930 .

3. Matsunaga, S: Fujiki. H.: Sakata, D.: Fusetani, N. Tetrahedron $1991,47,2999$

4. Matsunaga, S.: Wakimoto, T.: Fusetani, N. Tetrathedron Lett. 1997.38 .3763

5. Matsunaga. S.: Wakimoto. T.: Fusetani. N. J. Org. Chent 1997. 62.2640

6. Wakimoto. T.: Matsunaga, S.: Takai, A.: Fusetani. N. Chem. Biol. $2002,9,309$

7. Nakao, Y: Takada. K: Matsunaga, S; Fusetani, N. Tetrahedron 2001. 57.3013

8. Luo. X.: Li. F.: Shinde. P. B.: Hong. J.: Lee. C. O.: Im. K. S.: Jung. J. H. J. Nat Prod 2006. 69. 1760

9. Bao, B.: Sun. Q: Yao, X.: Hong. J: Lee. C. O.: Cho, H. Y: Jung. I. H. J. Nat. Prod $\mathbf{2 0 0 7}, 70,2$.

10. Lee, J.: Wang W: Hong. J: Lee, C. O.: Shin, S. Inn. K. S.: Jung. J. H. Chent. Pharm. Bull. 2007, $55,459$.

11. Jung. J. H.: Shinde. P. B.: Hong. J.: Liu. Y.: Sim. C. J. Biochem. Sist. Ecol. 2007. 35.48
12. Fusetani. N.: Sugawara. T.: Matsunaga. S. J. Org. Chem. 1992. 57. 3828 .

13. Tsukamoto. S.: Matsunaga. S.: Fusetani. N.: Toh-e. A. Tetrahedron 1999. $55,13697$.

14. Paul. G. K.; Gunasekera, S. P; Longely, R. E.; Pomponi, S. A. d. Nat. Prod. 2002, 65, 59

15. Perry. N. B.: Blunt. T. W.: Munro. M. H. G.: Pannell. L. K. J. Ant. Chent Soc. 1988. 110. 4850 .

16. Perry. N. B.: Blunt. J. W.: Munro. M. H.: Thompsont. A. M. J. Org. Chem. 1990. $55,223$.

17. Simpson. J. S.: Garson, M. J:- Blunt, J. W.: Munro, M. H. G. Hooper. J. N. A. J. Sat. Prod $2000,63,704$.

18. West. L. M.: Nothcote. P. T.: Hood. K. A.: Miller. T. H.: Page. M. J. J. Not. Prod 2000. 63.707

19. Sakemi. S.: Ichiba. T.: Kohmoto. S.: Saucy. G.: Higa. T. J. An. Chem. Soc. 1988, 110. 4851 .

20. Matsunaga. S.; Fusetani, N.: Nakao, Y. Tetahedron 1992, 48.8369

21. Kobayashi, J.; Itagaki, F; Shigemori, H.; Sasaki. T. J. Kat. Prod. 1993. 56.976

22. Vuong. D.: Capont. R. T.: Lacey. E.: Gill. .T. H.: Heiland. K.: Friedel. T. J. Kat.Prod. 2001. 64.640.

23. Clardy, J.; He. H. L. S. Patent 1995. 5.476 .953$.

24. Chen. S. P.: Ahmed, A. F.: Dai. C. F.: Lu, C. K.: Hu, W. P.: Wang. J. J.: Sheu. J. H. Tetrahedron 2006. 62.6802.

25. Chill. L.: Rudi. A.: Benayahu. Y.: Schleyer. M.: Kashmant. Y. Org. Lett. 2004. 6.755

26. Jayasuriya. H.: Guan. Z.: Polishook. J. D.: Dombrowski. A. W. Felock, P. J.; Hazuda. D. J.: Singh, S. B. J. Nat. Prod 2003. 66. 551 .

27. Marfey P. Carlsberg Res. Conmum. 1984. 49, 591

28. Pavan. M.: Bo. G. Phsiol Contpar. Oceol 1953. 3. 307.

29. Mever. B. N.: Ferrigni. N. R.: Putnam. J. E.: Jacobsen. L. B.: Nichols. D. E.: McLaughlin. I. L. Planta Med. 1982. 45.31. 